Матеріали Всеукраїнської науково-практичної конференції «Актуальні питання діагностики, лікування, раціональної фармакотерапії, диспансеризації та реабілітації в практиці сімейного лікаря» УДК 616.37-002.2-06:616.12-005.4]-02:616-056.5

DOI

\title{
ЗВ'ЯЗОК ПОКАЗНИКІВ ЛІПІДНОГО ОБМІНУ ІЗ КЛІНІЧНИМИ ПАРАМЕТРАМИ ХРОНІЧНОГО ПАНКРЕАТИТУ НА ТЛІ СТАБІЛЬНОЇ ІШЕМІЧНОЇ ХВОРОБИ СЕРЦЯ
}

๑Л. С. Бабінець, Н. А. Мельник

ДВНЗ «Тернопільський державний медичний університет імені І. Я. Горбачевського МОЗ України»

Гіперліпідемія лежить в основі розвитку як хронічного панкреатиту (ХП), так і стабільної ішемічної хвороби серця (CIXC). Недостатньо вивченою залишається залежність порушень ліпідного гомеостазу від клінічних параметрів ХП у хворих з коморбідністю ХП та СІХС.

Мета - дослідити вплив віку та тривалості ХП на глибину порушень ліпідного гомеостазу у хворих з коморбідним перебігом ХП та СIXC, зокрема із стенокардією напруги I-II функціональних класів (CH I-II ФК).

Вивчено медичні карти 46 хворих на ХП у поєднанні з СІХC (CH I-II ФК). Серед обстежених було 27 чоловіків (58,70\%) та 19 жінок (41,30\%). Середній вік хворих становив $(56,01 \pm 5,76)$ років, тривалість ХП- $(14,38 \pm 0,74)$ років, тривалість коморбідності ХП та СІХC - $(6,31 \pm 1,26)$ років. Ліпідний обмін оцінювали за показниками ліпідограми.

Аналізуючи показники ліпідограми, у всіх хворих на ХП+СІХС було встановлено наявність гіпер- та дисліпідемії. Тривалість ХП у цих хворих знаходилася у достовірно прямому помірному зв'язку із рівнями тригліцеридів (ТГ) $(r=0,64)$, ліпопротеїдів низької щільності (ЛПНЩ) $(r=0,43)$ і ліпопротеїдів дуже низької щільності (ЛПдНЩ) $(r=0,35)$ та у оберненому помірному зв'язку із рівнем ліпопротеїдів високої щільності (лПВЩ) ( $r=-0,53)$. Така ж взаємозалежність простежувалася між віком хворих та рівнями ТГ $(r=0,62)$, ЛПНЩ $(r=0,69)$, ЛПДНЩ $(r=0,59)$ та ЛПВЩ $(r=-0,60)$.

Висновок. Вік і тривалість ХП призводять до поглиблення порушень у ліпідному обміні в хворих з коморбідним перебігом ХП та CIXC (CH I-II ФK).

Перспективи подальших досліджень - продовжити дослідження впливу порушень ліпідного обміну на основні клініко-діагностичні параметри ХП у хворих на ХП в поєднанні із СІХC, зокрема із $\mathrm{CH} \mathrm{I}-\mathrm{II}$ ФK. 